Original articles

J. Perinat. Med. 15 (1987) 515

\section{Effectiveness of neonatal transport systems}

\author{
Helmut Saule $^{1}$, Klaus Riegel ${ }^{2}$, and Christian Beltinger ${ }^{1}$ \\ 12nd Children's Hospital, Augsburg, and 2Neonatal Department of the Children's \\ Hospital, University of Munich, West Germany
}

\section{Introduction}

In the early 1970's high-risk neonates were generally referred from obstetric clinics to neonatal units with insufficient support after birth and during transport. To counter this, pediatricians established neonatal transport services. Due to the enthusiasm of pediatricians and pediatric nurses these services still operate. Although articles have been published on the structure, organization and the equipment of transport systems $[1,7,10,12$, $13,17,19]$, reports about their effectiveness have been few in number $[3,11,18,21]$. There are both obstetricians as well as pediatricians who claim that critically ill infants who are transferred have the same prognosis as "inborn" infants at perinatal centers, if expert care after delivery is followed by safe transport with skilled neonatal intensive care. Sometimes this may be true, but it is not applicable to newborn care in general.

It is the object of the following evaluation to survey the effectiveness of regional neonatal transport systems.

Definition of effectiveness: Evaluating the quality of medical care (effectiveness) is one part of the concept of quality. It is defined as the ratio of an actually achieved result of a diagnostic and/or

\section{Abbreviations used:}

BPS Bavarian Perinatal Survey

ISB Institute for Medical Statistics and Biomathematics, University of Munich

LBW low birth weight

NICU neonatal intensive care unit

RD respiratory distress

RDS respiratory distress syndrome

\section{Curriculum vitae}

Helmut SAule was born in 1944 in Augsburg, Germany. He graduated from the University of Munich School of Medicine in 1970. Since 1972 he has been on the staff of the second Children's Hospital, Augsburg. His main fields of interest are neonatal intensive care and research in standards of medical care.

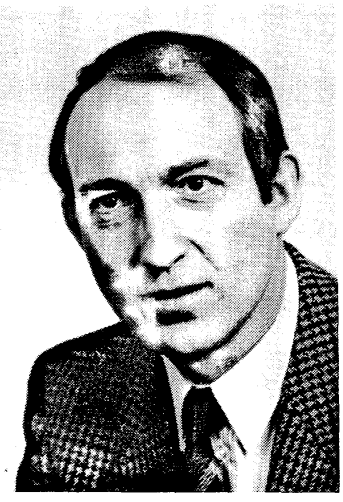

therapeutic medical action to the expected one. A medical activity is "effective", if it contributes a patient-specific success which could not be obtained without the professional services rendered. We have to find out whether the program does more good than harm when implemented under normal field conditions [21]. There are, however, difficulties in the definition and measurement of the outcome even in the field of neonatal transport. Since this is partly due to the lack of valid and process-specific outcome indices, the assessment of effectiveness must focus upon the medical process; this can be done using criteria described below.

\section{Materials and methods}

The following analysis is based on data of the ARVO-YLPPÖ study. Its aims, structure, methods and some results have been described elsewhere [15]. In this report all neonates with 
birth weights below 2000 grams delivered in Southern Bavaria (approximately 58,000 deliveries per year in 163 obstetric units) between 1979 and 1981 and referred to one of 19 children's hospitals within the first ten days of life were considered.

Data of health condition, clinical course, diagnosis, therapy and outcome was collected using a questionnaire. Anonymity was guaranteed to both participating hospitals and patients. The data were evaluated centrally at the ISB.

Obstetric data were obtained from the Bavarian Perinatal Survey (BPS) which required documentation of the course of pregnancy and delivery of the corresponding mothers. Not all obstetric departments participated in this survey. As the two surveys were run independently and personal data had to be plotted out, matching mothers and infants questionnaires was only possible in $85 \%$ of the cases in the Munich area and $50 \%$ of the cases in the South Bavarian area [15]. Regional perinatal care cases can be divided into three categories:

1. The child was born at a perinatal center i. e. a level III hospital, and was subsequently referred to the attached NICU $(\mathrm{N}=3)$. One NICU also admitted babies from obstetric departments in the Munich area. Before 1982 the Munich perinatal centers were the only perinatal centers in Southern Bavaria.

2. The child was born at an obstetric clinic in the Munich area (radius $30 \mathrm{~km}$ ) and referred to a NICU in a pediatric hospital in Munich $(\mathrm{N}=5)$.

3. The child was born at an obstetric clinic in Southern Bavaria (outside the Munich area) and was referred to a NICU in one of the regional children's hospitals $(\mathrm{N}=11)$.

Primary neonatal care can be classified by the presence or absence of a pediatrician 1) at birth, 2) after birth, and 3) during transport. In clinical practice the following combinations are of importance:

- A pediatrician trained in neonatalogy attended delivery and accompanied the subsequent neonatal transport to NICU (PAT). In areas without a perinatal center transfer was carried out by regional neonatal transport teams.

- A pediatrician arrived after birth in the referring hospital and performed the neonatal transport to NICU (PT).
- Primary care in the delivery room and neonatal transport to NICU were organized and performed by obstetric units (i. e. obstetricians, midwives, nurses, etc.) ( $\mathrm{T})$.

Criteria of effectiveness for regional neonatal transport activities should reflect not only the effects of primary care but also the risks of neonatal morbidity. The following parameters were chosen for risk:

- Referral during the first day of life: The Munich Perinatal Survey [20] demonstrated that newborns referred within the first 24 hours of life contribute $92 \%$ of neonatal mortality.

- Unfavorable conditions after birth are described by the following findings on admission:

Apgar score below 8,

body temperature below $36^{\circ} \mathrm{C}$,

Silverman score of 3 or more,

intubation and mechanical ventilation.

- Early neonatal mortality was used as a global outcome index.

\section{Results}

Table I summarizes the data of 248 patients from the Munich perinatal centers and compares them with the other regions. These babies demonstrate a higher incidence of unfavorable conditions on admission to the NICU and a lower mortality rate. Half of the infants were intubated $(58.8 \%)$ and ventilated $(50.8 \%)$; half of the rest suffered from RD (25.8\%). Nevertheless, the mortality was low $(6 \%)$.

In the group receiving continuous care by neonatologists (PAT, I) the highest accumulation of risks is combined with the lowest mortality rate $(4.8 \%)$. This also emphasizes the necessity for the effectiveness of primary care by pediatricians. This was provided in only $75 \%$ of referred babies. The data of neonates receiving primary care by obstetricians are listed in column T, I. One quarter of these had a low Apgar score on admission and $2 / 3$ of them were hypothermic (64\%). Only half of $47 \%$ intubated infants were ventilated. These findings were associated with a remarkably higher mortality $(8.5 \%)$.

Sevenhundred and thirty-six infants were referred to pediatric hospitals in the Munich area (table I). Approximately 6 out of 10 newborns (64.5\%) were initially cared for, and transferred by, a pediatrician (PAT, II). Every fifth patient $(20.5 \%)$ re- 
Table I. "Morbidity" and early neonatal mortality of referred infants (birth weight $<2000 \mathrm{~g}$ ).

\begin{tabular}{|c|c|c|c|c|c|c|c|c|c|c|c|c|c|}
\hline \multirow{3}{*}{\multicolumn{2}{|c|}{$\begin{array}{l}\text { Categories of primary care* } \\
\text { Regions of perinatal care } \\
\text { No. of infants }\end{array}$}} & \multicolumn{3}{|l|}{ PAT } & \multicolumn{3}{|l|}{ PT } & \multicolumn{3}{|l|}{$\mathrm{T}$} & \multicolumn{3}{|l|}{ Total } \\
\hline & & I & II & III & I & II & III & I & II & III & I & II & III \\
\hline & & 186 & 475 & 260 & 3 & 151 & 168 & 59 & 110 & 253 & & 736 & 681 \\
\hline $\begin{array}{l}\text { Transfer on first day } \\
\text { of life }\end{array}$ & $(\%)$ & 90,5 & 92,8 & 97,8 & (67) & 93,4 & 97,8 & 98 & 61,8 & 96,4 & 91,5 & 88,3 & 97,2 \\
\hline \multicolumn{14}{|l|}{ At admission: } \\
\hline $\begin{array}{l}\text { Condition impaired/ } \\
\text { bad }\end{array}$ & $(\%)$ & 46,2 & 54,4 & 51,5 & (100) & 51,0 & 43,0 & 37 & 40,9 & 43,5 & 44,8 & 51,8 & 46,2 \\
\hline Apgar score $<8$ & $(\%)$ & 16,7 & 24,2 & 18,8 & (33) & 23,2 & 16,7 & 25 & 9,1 & 22,9 & 19,0 & 21,7 & 19,8 \\
\hline Temperature $<36^{\circ}$ & $(\%)$ & 38,7 & 33,0 & 36,6 & (67) & 37,1 & 28, & 64 & 24,6 & 47,8 & 45,2 & 32,6 & 38,8 \\
\hline Silverman score $\geqslant 3$ & $(\%)$ & 32,8 & 13,5 & 34,6 & - & 13,2 & 25,0 & 5 & 10,0 & 31,2 & 25,8 & 13,2 & 31,0 \\
\hline Intubation & (\%) & 61,8 & 53,5 & 35,4 & (67) & 45,7 & 26 , & 47 & 5,5 & 4,7 & 58,8 & 44,7 & 21,7 \\
\hline Mech. ventilation & $(\%)$ & 60,7 & 52,0 & 33,5 & (33) & 43,0 & 24,5 & 22 & 3,6 & 5,5 & 50,8 & 42,9 & 20,9 \\
\hline Early neonatal & $(\%)$ & 4,8 & 14,1 & 21,2 & (33) & 12,6 & 11,9 & 8,5 & 5,5 & 12,3 & 6,0 & 12,5 & 15,6 \\
\hline
\end{tabular}

I: "Inborn" infants born in perinatal centers and transferred after delivery to the attached NICU.

II: Infants transferred after delivery in the Munich area to children's hospitals in Munich.

III: Infants transferred after delivery in the Southern Bavaria area to regional children's hospitals.

* for definitions see text

ceiving primary care by an obstetrician was later referred for care supervised by a pediatrician (PT, II). We assume that in these cases the Munich transport team was called too late, or arrived too late, to provide primary care and could only accompany the postnatal transfer. Approximately $88 \%$ of referrals took place during the first day of life. Since the presence of a pediatrician at delivery may be considered as an indicator of neonatal risk, one would expect an accumulation of unfavorable conditions in the groups receiving primary care from a pediatrician.

Yet, there is no difference in the status and mortalities of groups PAT and PT. The risks seem to be equally distributed in the two groups. The mortality rates $(14.1 \%$ and $12.6 \%)$ are about double that of infants born and cared for in $\mathrm{Mu}-$ nich level III hospitals, even though the "cardiorespiratory morbidity" on admission was lower in the groups of infants not born at perinatal care centers. One hundred and ten LBW infants $(\mathbf{1 4 . 9 \% )}$ were born in maternity hospitals without pediatric (and some without medical) attendance (T, II). Nearly $40 \%$ of them were referred after the first day of life. One could question whether these babies, who had a tendency to develop hypoglycemia and hypocalcemia, were adaequately cared for at these obstetric clinics.
Fewer transports to regional pediatric hospitals were accompanied by pediatricians in Southern Bavaria than in the Munich area. Four hundred and twenty-eight of 681 referrals $(62.8 \%)$ were carried out by pediatric transport teams. In $38.2 \%$, the pediatrician was present at delivery (PAT, III). In $24.6 \%$ of high-risk deliveries with subsequent postnatal transfer, the pediatrician was called or arrived too late (PT, III); every fourth infant was intubated $(26.2 \%)$ and ventilated $(24.5 \%)$; and a quarter (25\%) suffered from RD.

Two hundred and fifty-three infants $(27.2 \%)$ were transported without a pediatrician in attendance (T, III). Their general condition was impaired in about $40 \%$ of the cases. Hypothermia and RD were present in $47.8 \%$ and $31.2 \%$ respectively, and their mortality rate was high $(12.3 \%)$. We can assume that both risks at birth and during transport were underestimated.

The evaluation of care in perinatal departments outside of Munich demonstrated a correlation between the mode of primary medical services and the conditions of the infants on admission. An accumulation of unfavorable conditions were found in the PAT-group (continuous pediatric care). Every third infant (33.5\%) was already ven- 
tilated on admission, another third (34.6\%) suffered from RD. Infants, who received primary care at an obstetric unit and were then transferred under the supervision of a pediatrician (PT), demonstrated a lower incidence of impaired condition (43\%), hypothermia (28\%), RDS (25\%) and mechanical ventilation $(24.5 \%)$. Similarly the mortality rate $(11.9$ vs. $21,2 \%)$ was significantly lower.

From these results we can conclude: A LBW infant who has to be transported from an obstetric department to a pediatric clinic receives no benefit from continuous pediatric care starting at delivery. Or in other words: it seems to be insignificant whether primary neonatal care is performed by obstetricians or pediatricians as long as the postnatal transfer is organized by a pediatric transport team.

A comparison of data for infants transported to pediatric hospitals in Munich and in Southern Bavaria shows some differences between these two regions.

1. Upon admission to Munich hospitals, $42.9 \%$ of infants were ventilated, $13.2 \%$ of the nonventilated infants had $R D$, i. e., more than $50 \%$ suffered from respiratory problems and two thirds of these required ventilatory support. Although the incidence of neonatal respiratory failure in the region of Southern Bavaria was equally high $(51.9 \%)$ and "morbidity" on admission was also similar the incidence of ventilatory support was much lower $(20.9 \%)$. Apparently the policy for artificial ventilation in the therapy of babies with RD varied from region to region.

2. The mortality of the PAT-group in Munich was lower than in Southern Bavarian (14.1 vs. $21.2 \%$ ). This may perhaps be related to the available resources, as well as obstetric performance, pediatric skill, and distance from maternal to neonatal departments. These aspects could not be analyzed in this retrospective study.

\section{Discussion}

The study demonstrated that patterns of primary care of high-risk infants differ from region to region especially in regard to availability of a skilled pediatrician at birth. There is, however, no alternative to unbroken and expert care for the baby from the time of delivery until discharge. We believe that a pediatrician trained in neonatalogy is best able to provide all the needs of neonatal care.

The data in the table show that neonatal transport teams often arrived at the maternity hospitals after delivery had taken place. In the Munich area this happened in about $25 \%$ of cases, and in the Southern Bavaria in about $40 \%$. This is not surprising. Neonatal transport systems were not established to take care of emergencies in obstetric departments. The longer the distance between the obstetric and the pediatric clinic, the earlier the transport team has to be informed. Even in a perinatal center it takes about 15 minutes for the pediatrician to arrive in the delivery room and to prepare the essential facilities for resuscitation. It is clear that a pediatric transport team must either wait around in the delivery room for minutes to hours, or risk arriving too late occasionally. The fact that the Munich transport team arrived in time more often than the regional rescue teams can be explained by the shorter distances to the maternity hospitals. In Munich, they are within a radius of $30 \mathrm{~km}$ and can be reached within about 30 minutes. In the other regions, rescue teams have to cover distances up to $103 \mathrm{~km}$. It is evident that it is frequently impossible to arrive on time in emergency cases.

Neonates born in perinatal centers in Munich had a better outlook for survival than babies referred from outside, regardless of whether they had had continuous care by a pediatrician or not. Although morbidity on admission was lower in the "outborn" group, the neonatal mortality was at least twice that of the "inborn" group. The high incidence of RDS in "outborns" may perhaps reflect a lower standard of obstetric care, which later led to increased neonatal mortality. An unpublished assessment of pediatric clinics in Southern Bavaria revealed deficits in the size and qualification of medical and nursing staffs. Even in $\mathrm{Mu}-$ nich with three University pediatric hospitals, mortality rates of LBW infants are high. We must assume that the risks of transportation of LBW infants are fairly high. Our data support the conclusion that LBW infants benefit from antenatal maternal transport and birth in a perinatal center $[4,5,6,8,9,14,15]$.

It is interesting that continuous pediatric care from the time of delivery did not improve survival rates of "outborn" infants transported to a $\mathrm{Mu}$ - 
nich hospital or to a regional pediatric department after birth. This is surprising since in Munich perinatal centers the presence of pediatric staff at birth contributed to decreased mortality rates.

This can be explained in two ways: The skill of the pediatricians in the transport teams did not exceed that of the obstetricians. This might be true in some cases: It is impossible to send the most experienced neonatologist to all high risk deliveries in outlying hospitals. However, in general the staffing and skill of neonatal transport teams are quite good.

It is more likely that the benefits which can be provided by a pediatrician at birth have been overestimated and the risks of transport have been underestimated. Environmental and/or unpredictable influences affecting the neonate during transit may undo the work of the pediatrician in the delivery room $[2,16]$. Although in the last few years there has been an improvement in the monitoring of infants in the ambulance, there has been no change in the specific environmental factors of transportation (i.e., ambulance cars, incubators, traffic, road conditions) which could make transport safer for vulnerable LBW infants. However, it is possible that the neonatal outcome would have been even more unsatisfactory without primary pediatric care.

\section{Conclusions}

The present study demonstrates that the effectiveness of neonatal rescue systems is limited. When high risk is predictable, especially in cases of threatened birth before 33 weeks of gestation, the mother must be referred to a perinatal center early enough to arrive before birth. In these centers comprehensive maternal-fetal-neonatal services are available around the clock. Special transport systems are, nevertheless, necessary for unpredictable emergencies, i.e., deliveries of sick or malformed newborns. All services should be regionalized to improve effectiveness. A system of regional perinatal centers must be established before a high risk maternal transport system can be installed.

\section{Summary}

In order to assess the effectiveness of neonatal transport systems, morbidity on admission and early neonatal mortality of low birth weight infants below $2000 \mathrm{gm}$ were studied. All infants referred to a neonatal department in Munich or Southern Bavaria from 1979 to 1981 were included. The data of infants born in Munich perinatal centers were compared to those of infants delivered in hospitals in the Munich area (radius $30 \mathrm{~km}$ ) and in other hospitals in Southern Bavaria. Ninetyfour percent of $248 \mathrm{LBW}$ neonates born in the Munich perinatal centers, $87.5 \%$ of 736 infants and $84.4 \%$ of $681 \mathrm{LBW}$ infants from the Munich area and Southern

Bavaria respectively survived the first week of life although the morbidity risks of inborn infants were higher than those of the outborn. The presence of a pediatrician at birth and during neonatal transport to an NICU did not improve survival rates of infants delivered outside the perinatal centers.

The effectiveness of neonatal transport systems is limited. They should be complemented by a maternal transport system, i.e., an infant transport in utero for cases in which the necessity for intensive neonatal care is expected.

Keywords: ARVO-YLPPÖ-study, effectiveness of neonatal care, neonatal transport systems, perinatal care regionalization.

\section{Zusammenfassung}

Effektivität von Neugeborenen-Transportdiensten

Anhand von Kriterien zur „Morbidität bei stationärer Aufnahme" sowie der Frühsterblichkeit wurde bei verlegten untergewichtigen Neugeborenen die Effektivität von Neugeborenen-Transportdiensten geprüft. Alle dysmaturen Kinder mit Geburtsgewichten unter $2000 \mathrm{~g}$, die in den Jahren 1979-1981 in eine Münchner bzw. eine südbayerische Kinderklinik eingewiesen wurden, gingen in die Untersuchung ein. Die Daten der „intern Verleg- ten" in den Münchner Perinatalzentren wurden mit denen auswärtiger Zuweisungen im Großraum München bzw. dem restlichen Südbayern verglichen.

Von 248 Kindern aus den Perinatalzentren überlebten trotz höchster „Aufnahmemorbidität“ 94\%. Bei auswärtigen Einweisungen nach München $(n=736)$ oder in eine südbayerische Abteilung $(n=681)$ lagen die Überlebensziffern mit 87,5 bzw. $84,4 \%$ erheblich niedriger; eine durchgehende pädiatrische Betreuung ab Geburt 
und auf dem Transportweg ließ keine positiven Auswirkungen auf die Ergebnisse erkennen. Die Effektivität von Neugeborenen-Transportdiensten ist beschränkt. Letztere sollten ergänzt werden durch Transporteinrich- tungen für Hochrisikoschwangere, d. h. eine zeitgerechte ,in utero-Verlegung“ gefährdeter Feten in leistungsfähige Perinatalzentren.

Schlüsselwörter: ARVO-YLPPÖ-Studie, Effektivität der Neugeborenenversorgung, Neugeborenen-Transportdienste, perinatalmedizinische Regionalisierung.

\section{Résumé}

\section{Efficacité des systèmes de transport néonatal}

Nous avons étudié les risques de morbidité à l'admission et la mortalité néonatale précoce des enfants de faible poids de naissance (inférieur à $2000 \mathrm{~g}$ ), dans l'optique d'évaluer l'efficacité des systèmes de transport néonatal. Ont été inclus tous les enfants rattachés à un départment néonatal à Munich et dans le sud de la Bavière au cours des années 1979 à 1981 . Les données concernant les enfants nés à Munich dans les centres périnataux ont été comparées à celles des enfants nés dans l'aire de Munich (rayon de $30 \mathrm{kms}$ ) et dans les autres hopitaux du sud de la Bavière. $94 \%$ des 248 nouveaux-nés de faible poids de naissance nés dans un centre périnatal et
87,5 des enfants de faibles poids de naissance nés dans l'aire de Munich et le sud de la Bavière ont survécu après la première semaine de vie bien que les risques de morbidité des enfants nés sur place soient plus élevés que ceux nés à l'extérieur. La présence d'un pédiatre à la naissance qui ultérieurement prend en charge la transport néonatal vers le centre n'améliore pas les résultats concernant les enfants nés en dehors des centres périnataux. L'efficacité des systèmes de transport néonatal est limitée. Ils devraient être associés à un système de transport des mères à haut-risque, c'est-à-dire un transport de l'enfant in utero, lorsque des soins intensifs néonataux sont prévus.

Mots-clés: Efficacité des soins néo-nataux, étude ARVO-YLPPÖ, régionalisation des soins périnataux, systèmes de transport néonatal.

\section{References}

[1] Blake AM, N Mc Intosh, EOR Reynolds, DST ANDREW: Transport of newborn infants for intensive care. Br Med J II (1975) 13

[2] Boenisch H, W Gaden, G MaU, U Gohrbrandt, HO TeUteBerg, H Braun, HJ BEERMANN: Mechanische Belastungen Neugeborener bei Inkubatorfahrten. Monatsschr Kinderheilkd 133 (1985) 471

[3] Chance GW, JD Matthew, J Gash, G Williams, K CUNNINGHAM: Neonatal transport: A controlled study of skilled assistance. J Pediatr 93 (1978) 662

[4] ChISwick ML: Perinatal referral: a time for decisions. Br Med J 285 (1982) 83

[5] COoKE RWI: In utero transfer to specialist centres. Arch Dis Child 58 (1983) 483

[6] CORDERo L, CR BaCKes, FP ZuSPAN: Very lowbirth weight infant. I. Influence of place of birth on survival. Am J Obstet Gynecol 143 (1982) 533

[7] DaNGel P: Der Transport von Risikoneugeborenen. Pädiat Fortbild K Praxis 41 (1975) 59

[8] Giles HR, J Isaman, WJ Moore, CD Christian: The Arizona high-risk maternal transport systems. Am J Obstet Gynecol 128 (1977) 400

[9] HARRIS TR, J ISAMEN, HR GILES: Improved neonatal survival through maternal transport. Obstet Gynecol 52 (1978) 294
[10] HÖRNCHEN H, P BRETSCHNEIDER, HP SCHMITZ VON DEN DRIESCH, J MARENBerG: Transport von Frühgeborenen, Neugeborenen und Säuglingen unter Intensivpflegebedingungen. Med Klin 74 (1979) 1033

[11] Lazzara A, WP Kanto, FD Dykes, P Ahmann, $\mathrm{K}$ WeST: Continuing education in the community hospital and reduction in the incidence of intracerebral hemorrhage in the transported preterm infant. J Pediatr 101 (1982) 757

[12] Lemburg P, U Enayat, K Renner, B Volberg: Praktische Erfahrungen mit dem IntensivpflegeTransport von Früh- und Neugeborenen bei vitaler Gefährdung. Wien Klin Wochenschr 87 (1975) 468

[13] LösCher T, R ORTLIEB, H SAULE: Abholdienst zum Transport gefährdeter Früh- und Neugeborener. In EMMRICH P (ed): Pädiatrische Intensivmedizin, vol 3. Thieme Verlag, Stuttgart-New York 1977

[14] Modanlou HD, W Dorchester, RK Freeman, C RoMmAL: Perinatal transport to a regional perinatal center in a metropolitan area: maternal versus neonatal transport. Am J Obstet Gynecol 138 (1980) 1157

[15] Riegel K, HK Selbmann, K Österlund: PerinatalRisiken und kindliche Mortalität und Morbidität. GSF, München 1985 
[16] Shenai JP, GE Johnson, RV Varney: Mechanical vibration in neonatal transport. Pediatrics 68 (1981) 55

[17] SCHÖBER JG, D PETERS, T Noss: Transport von Risikoneugeborenen. Münch Med Wochenschr 122 (1980) 589

[18] Schoetzau A, JG Schöber, HK Selbmann: Läßt sich die Indikation für den Abruf des Neugeborenen-Notarzt-Dienstes (NNAD) vor Geburt stellen? Z Geburtshilfe Perinatol 187 (1983) 138

[19] Sumners J, HB Harris, B Jones, G Cassady, DD WIRTSCHAFTER: Regional neonatal transport: impact of a integrated community/center system. Pediatrics 65 (1980) 910
[20] Selbmann HK, M Brach, H Elser, K HolzmanN, J Johannigmann, K RIEGel: Münchner Perinatalstudie 1975-1977. Deutscher Ärzte-Verlag, Köln 1980

[21] Sinclair JC, SW Torrance, MH Boyle, SP HorWOOD, S SAIGAL, DL SACKETT: Evaluation of neonatal intensive care programs. N Engl J Med 305 (1981) 489

Received Mai 12, 1986. Accepted September 29, 1986.

Dr. Helmut Saule

II. Kinderklinik

Stenglinstraße 2

D-8900 Augsburg, West Germany 


\section{Receptor Medioted Antisteroid Action}

Editor M. K. Agarwal

$1987.17 \mathrm{~cm} \times 24 \mathrm{~cm}$. VIII, 524 pages. Numerous illustrations. Hardcover. DM 298,-; approx. US \$175.00 ISBN 3110113554

This volume groups together latest conceptual developments and ongoing designs for antagonists in all groups of steroid hormones at the pharmacological, biochemical, and clinical level. New biochemical and immunocytochemical approaches to probe the nature of receptor localization and function have been reviewed as well. The influence of antisteroids in modifying behaviour, steroid hormones in insects, and the approach of idiotype selection to study hormone action, have been included to give the volume even wider appeal.

All authors are active in the fields in which they have contributed and the collection of papers by experts under one single cover provides the opportunity to glance at material one would not otherwise read. It is certain that this multidisciplinary approach will lead to the cross fertilization of ideas so necessary for further conceptual and practical effort to dissect the receptor and use it to alleviate disease.

Price is subject to change without notice

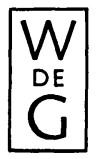

de Gruyter · Berlin · New York 